\title{
PEMBERDAYAAN EKONOMI PEREMPUAN PERSPEKTIF GENDER DAN EKONOMI ISLAM: STUDI KASUS AKSES PENGUSAHA UMKM PEREMPUAN TERHADAP LEMBAGA KEUANGAN SYARIAH BMT DI PALEMBANG
}

\author{
Maftukhatusolikhah $^{1)}$, Dwi Budiarto ${ }^{2)}$ \\ ${ }^{1}$ Universitas Islam Negeri Raden Fatah Palembang \\ email: maftukhatusolikhah_uin@radenfatah.ac.id \\ ${ }^{2}$ STIT NU Sumberagung, OKU Timur \\ email:
}

\begin{abstract}
Usaha kecil di Indonesia masih terus didominasi pelaku usaha mikero, di sisi lain UMK kesulitan mengakses pembiayaan dari bank, terlebib UMK yang dilakukan oleh perempuan, yang bisa jadi dipengarubi oleb berbagai faktor termasuk gender bias. Dengan tingginya gap perekonomian, maka lembaga keuangan dengan karakteristik. yang sesuai dengan pelaku UMK perempuan sangat dibutubkan. Dalam konteks tersebut tulisan ini melakukan kajian tentang pemberdayaan ekonomi perempuan, dengan menggunakan kerangka analisis gender dan perspektif ekonomi Islam. Untuk memperkuat data penelitian, studi kasus dilakukan terhadap akses perempuan pada lembaga kenangan berbasis syariah Baitul Maal wa at-Tamwil di Kota Palembang. Pemilihan Lembaga Kenangan Syariah berupa BMT dilakukan karena segmentasi BMT yang lebih akomodatif terhadap pengusaba-pengusaha UMK yang relative tidak "bankable". Penelitian bersifat qualitatif, yang menunjukkan basil babwa BMT merupakan Lembaga Kenangan berbasis syariah yang accessible atau memberikan akses yang terbuka dan luas bagi para pengusaha perempuan, hal ini dapat dilihat dari relative banyaknya perempuan yang menjadi nasabah pada beberapa BMT di Palembang. BMT dengan produk-produknya, merupakan lembaga keuangan yang sensitif gender' dan bisa semakin mendorong terwijudnya gender equalities, karena secara demikian BMT telah menganggap penting potensi, partisipasi, dan akses pengusaba UMK Perempuan terbadap sumber-sumber keuangan
\end{abstract}

Keywords: Pemberdayaan, Gender, UKMK, BMT

\section{PENDAHULUAN}

Pada Fenomena yang diangkat dalam sinetron "Dunia Terbalik" yang tayang setiap hari pada salah satu stasiun televisi swasta tanah air, menyiratkan paling tidak dua kesimpulan dalam kaitan antara perempuan dan ekonomi yaitu; pertama, perempuan atau ibu bisa mengambil peran pada sektor publik dalam hal ini peran sebagai pencari nafkah yang dalam "konstruksi gender" budaya Indonesia secara umum merupakan tugas laki-laki atau ayah; kedua, perempuan kurang mendapat akses yang memadai terhadap sumbersumber ekonomi di dalam negeri sehingga harus menjadi tenaga kerja wanita (TKW) di luar negeri.

Undang-undang Republik Indonesia Nomor 7 Tahun 1984 tentang Konvensi Mengenai Penghapusan Segala Bentuk Diskriminasi Terhadap Perempuan, menunjukkan bahwa secara positif-normatif laki-laki dan perempuan seharusnya memiliki status dan peranan (hak dan kewajiban) yang sama dalam berbagai bidang, termasuk bidang ekonomi. Namun pada dataran realitas, perempuan sering mengalami ketidak-beruntungan dan mempunyai akses yang lebih terbatas dalam berbagai bidang dibandingkan dengan laki-laki.

Di samping fenomena TKW di atas, sesungguhnya data menunjukkan bahwa 
pertumbuhan dan keberhasilan bisnis kalangan perempuan (di dalam negeri) menunjukkan nilai yang sangat signifikan. Saat ini diketahui bahwa 60\% dari 46 juta Usaha Mikro Kecil (disingkat UMK), pengelolaannya dilakukan oleh kaum perempuan. Dengan jumlah yang cukup banyak ini peran perempuan pengusaha menjadi cukup besar bagi ketahanan ekonomi, karena mampu menciptakan lapangan kerja, menyediakan barang dan jasa dengan harga murah, serta mengatasi masalah kemiskinan.

Di samping itu, UMK memberikan kontribusi besar dalam penyerapan tenaga kerja yaitu 97,16\% yaitu menyerap 4.535.970 tenaga kerja dari sektor usaha kecil (UK) dengan pertumbuhan 15,71\%, dibandingkan dengan tahun sebelumnya (2011) dan dari sektor usaha menengah (UM) sebanyak 3.262.023 tenaga kerja dengan pertumbuhan 14,67\% dibandingkan dengan tahun sebelumnya, dan dari usaha mikro (UMi) berjumlah 99.859.517 tenaga kerja dengan pertumbuhan sebesar 5,16\% dibandingkan tahun sebelumnya dan memberikan kontribusi terhadap Produk Domestik Bruto (PDB) sebesar Rp 4,869 triliun atau 59,08\%. (Antonio, 2017)

Praktik keuangan mikro muncul karena kebutuhan riil masyarakat. Dengan tingginya gap perekonomian, dimana usaha kecil masih terus didominasi pelaku usaha mikro, maka lembaga keuangan dengan karakteristik yang sesuai dengan pelaku UMK sangat dibutuhkan karena bisa dikatakan UMK kesulitan mengakses pembiayaan dari bank. UMK dianggap tidak bankable karena bentuk usahanya tidak memenuhi kriteria 5C: 1)Tidak memenuhi Character, karena UMK memiliki kelemahan dalam profil praktisinya; 2. Dianggap tidak memenuhi unsur Capacity, karena latar belakang Pendidikan pengusaha UMK mayoritas relatif rendah; 3. Terkait Capital, modal UMK rendah dan biasanya tidak ada pemisahan dana usaha dengan dana rumah tangga; 4. Terkait condition, UMK sangat sensitif dengan perubahan ekonomi dan lingkungan usaha; dan 5. Terkaitcollateral, UMK kesulitan menyediakan kolateral dalam akses Keuangan. (Antonio, 2017)

Secara kuantitatif jumlah perempuan lebih dari separuh jumlah penduduk Indonesia. Dalam jumlah tersebut perempuan merupakan kekuatan yang luar biasa dalam mendukung pembangunan dan pertumbuhan ekonomi. Dalam hal ini diperlukan komitmen bersama terhadap upaya mengatasi masalah-masalah yang dihadapi perempuan dalam menghapuskan kendala-kendala yang menghalangi terwujudnya kesetaraan dan keadilan gender dalam berbagai bidang termasuk bidang ekonomi-baik dari pihak lain ataupun-dari perempuan pelaku ekonomi. Oleh karena itu diperlukan suatu analisis yang bisa dijadikan rujukan untuk memperbaiki kondisi tersebut.

Dalam konteks tersebut tulisan ini akan mengkaji pemberdayaan ekonomi perempuan, dengan menggunakan kerangka analisis gender dan perspektif ekonomi Islam. Untuk memperkuat data penelitian, studi kasus dilakukan terhadap akses perempuan terhadap lembaga keuangan berbasis syariah Baitul Maal wa at-Tamwil di Kota Palembang. Pemilihan Lembaga Keuangan Syariah berupa BMT dilakukan karena segmentasi BMT yang lebih akomodatif terhadap pengusaha-pengusaha UMK yang relatif tidak "bankable".

\section{LITERATURE REVIEW DAN PENGEMBANGAN HIPOTESIS}

Perbedaan fisiologis yang alami sejak lahir pada umumnya dan kemudian diperkuat oleh struktur kebudayaan yang ada - khususnya oleh adat istiadat, sistem sosial ekonomi serta pengaruh pendidikan - sering melahirkan ketidakadilan/ ketimpangan gender (gender inequalities). (Kartono, 1989) Mansour Fakih membagi manifestasi ketimpangan gender dalam:1) marginalisasi atau pemiskinan perempuan, 2) subordinasi, 3) stereotipe, 4) kekerasan, 5) beban ganda dan 6) sosialisasi ideologi nilai peran gender. (Mansour Faqih, 
2012) Dalam konteks penelitian ini, kurangnya akses dan dukungan sektor keuangan atau perbankan terhadap pengusaha UMKM perempuan, bisa saja merupakan wujud dari gender inequalities ini, khususnya anggapan bahwa perempuan adalah subordinat sehingga potensi, partisipasi, dan aksesnya terhadap sumber-sumber keuangan dianggap tidak penting. Stereotipe terhadap perempuan juga mungkin saja menyebabkan hal tersebut, karena dalam masyarakat masih banyak citra baku budaya berupa pelabelan negatif yang disandangkan terhadap perempuan-misalnya adanya anggapan bahwa perempuan kurang rasional atau emosional dan kurang berpendidikan-sehingga dianggap sebagai second class.

Kurangnya keterlibatan perempuan, secara umum disebabkan oleh dua hal besar. Pertama perempuan belum bisa berperan sesuai dengan kemampuan yang dimilikinya karena budaya atau kebiasaan yang berlangsung selama ini. Kedua, adanya kendala pada perempuan itu sendiri yang secara tidak sadar merasa bahwa dirinya tidak harus berperan pada kegiatan-kegiatan tertentu yang semestinya dapat dijalani secara lebih aktif dan mendalam (Katjasungkana, 2010) Ideologi gender yang dibangun atas dasar budaya untuk mengatur relasi manusia, telah mengkonstruksikan pembagian kerja atas dasar jenis kelamin. Konstruksi sosial ini sedemikian kuatnya sehingga seolah-olah pembagian kerja atas dasar jenis kelamin tersebut dianggap kodrat. Pembedaan wilayah secara dikotomis antara wilayah publik dan domestik menjadi sangat kuat, sehingga pekerjaan bersifat domestik dilekatkan pada kaum perempuan dan pekerjaan yang bersifat publik dilekatkan pada kaum laki-laki.

Pembagian peran atas dasar jenis kelamin tersebut membuahkan hasil pembagian peran atas dasar jenis kelamin pula. Perempuan bekerja di sektor publik adalah tuntutan sebuah zaman, tetapi ternyata perubahan pandangan tentang peran gender perempuan dan laki-laki tidak sepesat perubahan zaman itu sendiri. Akibatnya bias gender sering terjadi dalam pandangan masyarakat yang menimbulkan berbagai macam ketidakadilan gender, termasuk dalam aspek kehidupan ekonomi. Dalam hal ini walaupun kenyataan menunjukkan bahwa seiring dengan berkembangnya waktu, ternyata tugas atau peranan perempuan dalam kehidupan keluarga semakin bertambah atau berkembang lebih luas, terutama karena tuntutan keadaan Namun karena secara umum masyarakat masih menganggap bahwa tugas perempuan dalam keluarga hanya melahirkan keturunan, mengasuh anak, melayani suami dan mengurus rumah tangga, perempuan sering menemui hambatan yang lebih berat dalam perluasan perannya. (Angger Wiji Rahayu, 2015)

UU No. 7 tahun 1984 Tentang Konvensi Mengenai Penghapusan Segala Bentuk Diskriminasi Terhadap Wanita (disingkat Konvensi Wanita), secara konkret menekankan kesetaraan dan keadilan antara perempuan dan laki-laki (genderequality and equity), persamaan hak dan kesempatan serta perlakukan adil disegala bidang dalam semua kegiatan meskipun diakui adanya perbedaanbiologi/kodrati antara perempuan dan laki-laki. Perbedaan gender ini antara lain menyebabkan perlakuan terhadap perempuan dimana perempuan dirugikan karena dianggap sebagai subordinasi laki-laki baik dalam keluarga maupun masyarakat. Hal ini juga melahirkan adanya pembatasan kemampuan dan kesempatan untuk memanfaatkan peluang yang ada untuk tumbuh berkembang secara optimal, menyeluruh dan terpadu dan Peluang untuk berperan dalam pembangunan dan menikmati hasil pembangunan. Perbedaan tersebut menempatkan perempuan pada kondisi dan posisi perempuan yang dianggap lebih lemah dibandingkan laki-laki karena sejak semula sudah dipolakan adanya diskriminasi dalam budaya adat atau karena lingkungan keluarga, masyarakat yang tidak mendukung adanya kesetaraan dan kemandirian perempuan (UU No. 7 tahun 1984)

Potensi perempuan dalam membuat pendapatan sendiri juga jauh lebih rendah daripada potensi yang dimiliki oleh laki-laki, sehingga perempuan dan keluarga yang 
diasuhnya merupakan anggota tetap kelompok masyarakat yang paling miskin. Namun penggalian potensi atau pemberdayaan perempuan lewat kegiatan ekonomi dengan muatan kebutuhan strategis akhir-akhir ini terus digencarkan. Seiring perkembangan zaman, perempuan yang dulu nasibnya hanya bergantung dengan suami untuk memenuhi kebutuhannya, saat ini sudah berubah. Tidak sedikit perempuan yang dapat memenuhi kebutuhannya bahkan ada yang penghasilannya melebihi suami (UU No. 7 tahun 1984)

Kegiatan pembangunan yang menggunakan pendekatan gender dan pembagunan, mengharapkan kegiatan perempuan tidak terpaku hanya untuk pemenuhan kebutuhan keluarga, tetapi mereka dilibatkan untuk memenuhi kebutuhan masyarakat pada umumnya. Perempuan dalam pembangunan dalam realitasnya telah menghasilkan kemiskinan perempuan dan memberikan multi beban pada mereka. Keterbatasan peran perempuan dalam kegiatan pembangunan ekonomi, baik sebagai penerima manfaat maupun sebagai kontributor dan pelaksana sering dipahami sebagai kurangnya kesempatan yang diberikan kepada perempuan, daripada melihat kenyataan adanya struktur yang timpang dalam masyarakat.

Dalam pedoman Instruksi Presiden RI No.9 Tahun 2000 Tentang Pengarusutamaan Gender dalam Pembangunan Nasional Tanggal 19 Desember 2000, disebutkan bahwa "Analisis Gender" adalah proses yang dibangun secara sistematik untuk mengidentifikasi dan memahami pembagian kerja/peran laki-laki dan perempuan, akses dan kontrol terhadap sumber-sumber daya pembangunan, partisipasi dalam proses pembangunan dan manfaat yang mereka nikmati, pola hubungan antara laki-laki dan perempuan yang timpang, yang di dalam pelaksanaannya memperhatikan faktor-faktor lainnya seperti kelas sosial, ras dan suku bangsa. Dengan analisis gender ini, persoalan kurangnya dukungan terhadap pengusaha UMKM perempuan, bisa dilakukan untuk memahami mengapa hal ini terjadi, dengan melakukan penelitian dengan berbagai sudut pandang dan subjek yang beragam.

Dalam konteks analisis gender tersebut, penelitian ini bermaksud mengidentifikasi dan memahami akses dan kontrol perempuan terhadap sumber-sumber daya pembangunan dalam hal ini sumber pembiayaan modal yang merupakan peran dari sektor lembaga keuangan. Dapat ditengarai bahwa sangat mungkin keterbatasan perempuan dalam mengakses sumber-sumber tersebut disebabkan oleh banyak faktor.

Endang Widuri (2008) mengemukakan bahwa ketertinggalan perempuan dibandingkan dengan laki-laki-bisa jadi-disebabkan dari dalam diri perempuan itu sendiri (faktor internal), maupun dari luar (faktor eksternal). Faktor internal perempuan antara lain: masih rendahnya dan terbatasnya motivasi perempuan di dalam meningkatkan dirinya untuk maju, sikap menerima dan pasrah terhadap keadaan, merasa rendah diri, tidak berdaya serta tidak mandiri. Gerak perempuan juga terkendala oleh ukuran-ukuran obyektif dari sumber daya manusia, misalnya rendahnya pendidikan dan pengetahuan, terbatasnya wawasan serta rendahnya ketrampilan sebagian perempuan dalam berbagai bidang. Adapun faktor eksternal perempuan dipengaruhi oleh faktor-faktor yang menyangkut nilai-nilai budaya masyarakat, tidak komprehensifnya penterjemahan ajaran agama, aturan hukum dan kebijakan serta pola pengambilan keputusan dalam berbagai bidang kehidupan yang masih bias gender. Nilai-nilai budaya patriarki mengakibatkan perempuan terdiskriminasi dalam berbagai bidang kehidupan yang berakibat terinternalisasinya sikap-sikap sebagai warga negara kelas dua.

Oleh karena itu kerangka analisis yang digunakan dalam penelitian ini adalah kerangka analisis gender dan kerangka analisis ekonomi Islam. Kerangka analisis gender digunakan untuk memperkenalkan secara singkat konsep gender dengan issu 
perempuan/gender dalam pembangunan ekonomi, khususnya terkait akses mereka terhadap sumber-sumber ekonomi dalam hal ini lembaga keuangan syariah. Dalam hal ini penekanan terletak pada pandangan bahwa pembangunan ekonomi dalam segala sektornya-termasuk sektor keuangan-tidak bebas nilai sehingga potensial menindas gender tertentu. Hal ini dimaksudkan untuk memberikan dasar-dasar analisis gender, yang dapat dijadikan dasar kebijakan gender (gender policy) pada lembaga-lembaga keuangan syariah ( dalam hal ini BMT), yang nota bene merupakan implementasi dari grand theorysistem ekonomi Islam.

Perempuan pengusaha dalam peran dan posisinya sebagai nasabah sektor keuangan - perbankan antara lain dilakukan oleh Natalie Sappleton (2009), Teresa Nelson, Sylvia Maxfield, Deborah Kolb (2009), Sari Retno Ayu Purnama (2014), serta Maftukhatusolikhah dan kawan-kawan (2018). Kajian dilakukan dari berbagai sudut yang beragam.

Natalie Sappleton (2009) membahas perempuan yang berkiprah di dunia usaha dan kaitannya dengan modal sosial sementara Deborah A. O'Neil, Margaret M. Hopkins, Sherry E. Sullivan, (2011) membahas perannya disebuah organisasi. Natalie Sappleton (2009) membahas perempuan yang berkiprah di dunia usaha dan kaitannya dengan modal sosial. Penelitian dilakukan dengan mengambil sampel terhadap kegiatan wirausaha yang dilakukan pria maupun wanita. Analisis regresi digunakan untuk menentukan dampak gender pemilik usaha, sektor perusahaan terhadap tingkat modal sosial mereka. Hasil kajian didapati bahwasanya wanita yang bekerja di wirausaha tradisional perempuan ditemukan memiliki tingkat tertinggi modal sosial. Berbeda sekali dengan pria dan wanita yang bekerja di wirausaha sektor tradisional laki-laki yang menunjukkan tingkat modal sosial yang lebih rendah. Faktor yang diukur dari segi kepercayaan, keterlibatan masyarakat dan jaringan sosial. Wirausaha di sektor tradisional atau non-tradisional gender ditemukan menjadi prediktor signifikan dari modal sosial.(Natalie Sappleton, 2009)

Sementara Teresa Nelson, Sylvia Maxfield, Deborah Kolb, (2009) mengeksplorasi isu yang berkenaan dengan pengaksesan perempuan terhadap modal usaha. Kajian difokuskan pada situasi yang dihadapi oleh perempuan pengusaha, serta strategi yang mereka jalankan untuk mendanai pertumbuhan bisnis yang tinggi dengan dana ventura. Kajian dilakukan terhadap konstruksi gender dan konstruksi sosial yang berlaku, pada kenyataan di lapangan, yang sangat mungkin memberikan diferensial konsekuensi untuk wanita dan pria dalam mengakses permodalan. Analisis menunjukkan bahwa wanita pengusaha bervariasi dalam mengidentifikasi secara luas mengenai gender terhadap usaha yang mereka kendalikan, dan tingkat perhatian dan perhatian manajemen terhadap yang ada.

Sari Retno Ayu Purnama (2014) membahas keterkaitan perempuan dengan kinerja keuangan UMK. Kajian ini bertujuan untuk mengetahui ada tidaknya pengaruh kinerja keuangan UMK terhadap pemberdayaan perempuan. Populasi penelitian ini adalah seluruh nasabah perempuan yang menerima kredit mikro dari BMT Kube Sejahtera Kota Padang untuk pembiayaan usaha kecil dan menengah. Hasil pengujian membuktikan bahwa kinerja keuangan UMK berpengaruh positif dan signifikan terhadap pemberdayaan perempuan. Kajian ini membataskan kajian pada nasabah perempuan yang menerima kredit mikro dari BMT dengan melihat kontribusi pendapatan dalam keluarga.

Maftukhatusolikhah dan kawan-kawan (2015) melakukan penelitian mengenai nasabah perempuan terkait efektivitas pembiayaan modal kerja, dengan menganalisis beberapa variabel yang melingkupi pengusaha perempuan yang menjadi nasabah perbankan syariah di kota Palembang yaitu: persepsi, perilaku, budaya dan kelas sosial. Berbeda dengan 
penelitian yang akan dilakukan terhadap nasabah pembiayaan BMT, penelitian tersebut menggunakan data nasabah perempuan yang menggunakan pembiayaan modal kerja di Perbankan Syariah yang masih aktif. Dari hasil analisis variabel perilaku dan budaya, dapat dilihat bahwa hal tersebut mungkin sangat terkait dengan masih perlunya pendidikan ataupun pengarusutamaan kesetaraan gender, karena terbentuknya perilaku dan budaya - sedikit banyak - dipengaruhi oleh budaya patriarki yang berkembang pada masyarakat Indonesia umumnya dan Kota Palembang pada khususnya.

Penelitian di atas memberi pijakan yang kuat terhadap penelitian yang akan dilakukan ini, sehingga mempunyai signifikansi dan masih layak untuk dilakukan, karena kekhusussan objek penelitian (pengusaha perempuan yang mendapat pembiayaan dari BMT) dan perluasan alat analisis, yang bukan hanya menggunakan analisis gender namun juga perspektif ekonomi Islam.

\section{METODE PENELITIAN}

Kajian difokuskan terhadap pengusaha UMKM perempuan yang mendapatkan pendanaan dari lembaga keuangan syariah BMT di kota Palembang, yaitu menganalisis pencapaian aspek pemberdayaan kaum perempuan dalam menanggulangi kemiskinan menggunakan analisis gender untuk menganalisis pembagian peran antara perempuan dan laki-laki di ranah domestik maupun ranah publik (mencari nafkah/ memenuhi kebutuhan ekonomi keluarga). Strategi yang digunakan untuk mengkaji persoalan penelitian ini adalah dengan penelitian lapangan atau studi kasus terhadap pengusaha perempuan yang mendapatkan pendanaan modal usaha dari BMT yang ada di Kota Palembang. Oleh karena itu dilakukan juga analisis dalam perspektif ekonomi Islam, karena BMT sendiri merupakan implementasi dari teori ekonomi Islam. Studi kasus ini ditujukan agar dapat memperoleh informasi yang mendalam, menyeluruh, rinci dan hasil yang mudah dipahami terkait objek kajian. Dengan studi kasus juga diharapkan dapat mengungkap pola-pola yang bersifat khusus tentang berbagai kondisi sosial yang ada di lokasi penelitian dalam hal ini Kota Palembang (Yin, 2014)

Untuk tujuan tersebut data yang digunakan dalam penelitian ini berupa data primer dan data sekunder. Data primer bersumber dari hasil wawancara dengan responden dan informan yaitu pengusaha UMKM Perempuan yang mendapat pembiayaan modal dari BMT dan dari pihak manajemen BMT. Data sekunder didapatkan dari dokumen-dokumen BMT dan buku-buku yang terkait dengan objek kajian. Oleh karena itu instrumen utama pengumpulan data penelitian ini adalah studi dokumentasi dan wawancara mendalam yaitu suatu teknik pengumpulan data primer dengancara mengajukan langsung pertanyaanpertanyaan kepada responden untukmemperoleh informasi mengenai pengalaman menjadi anggota, manfaat dankendala dalam menjalankan usaha dan mendapatkan pembiayaan modal usaha.

Data yang dikumpulkan dari sumber data (informan) akan dianalisis secara kualitatif dan disajikan dalam bentuk deskriptif analitis, serta sebagai penunjang akan ditampilkan dalam bentuk tabel maupun grafik setelah melalui proses reduksi data, penyajian data dan verifikasi, sehingga kesimpulan yang diambil sebagai hubungan antara data yang terkumpul merupukan hasil dari penelitian

\section{HASIL PENELITIAN}

Bagaimana akses permpuan khususnya perempuan yang menjadi penggerak usaha kecil dan mikro terhadap BMT yang ada di Palembang, dapat dilihat dari seberapa banyak 
anggota perempuan pada BMT yang menjadi nasabah produk-produk BMT khususnya produk pembiayaan, serta produk-produk apa saja yang bisa diakses perempuan dan bisa membantu para pengusaha perempuan untuk meningkatkan usaha dan penghasilan mereka.

Dari empat BMT di Kota Palembang yang dijadikan sampel penelitian ini, jumlah anggota atau nasabah perempuan pada institusi-institusi tersebut relatif banyak, bahkan hampir mendekati 50\% dari keseluruhan nasabahnya. Misalnya BMT Mitra Khazanah $46,8 \%$ atau 88 orang dari 188 nasabah produk pembiayaan adalah perempuan.

Dari beberapa produk yang ada pada semua BMT Tersebut, produk pada BMT Mitra khazanah dan BMT Insan Mulia, yaitu Pembiayaan Tanggung Renteng. Ilustrasi dari Tanggung renteng bahwa keanggotaan BMT dibagi dalam beberapa kelompok dalam konteks ini komunitas ibu-ibu. Satu kelompok katakanlah terdiri dari 20 orang. Apabila salah satu anggota membutuhkan dana dan dia ingin meminjam uang dari koperasi, maka 20 orang anggota kelompok tersebut bermufakat untuk menyetujui pinjaman atau tidak. Kelompok juga merumuskan aturan pengembalian, bentuk cicilan, dan sebagainya, termasuk resiko dan keuntungan yang ditanggung bersama.

Tanggung renteng melahirkan wewenang untuk menentukan anggota mana yang berhak mendapatkan pinjaman. Asumsinya, anggota kelompoklah yang lebih mengetahui kebutuhan dan kesanggupan anggota dalam mempertanggungjawabkan dana yang dipinjam. Apabila ada anggota yang meminjam tadi tidak dapat membayar cicilan, maka cicilan itu akan ditanggung bersama oleh seluruh anggota kelompok sehingga tidak ada penunggakan cicilan pada BMT. Di sini nilai saling percaya dan kebersamaan tersemi. Setiap anggota memiliki rasa empati pada anggota lain dan masyarakat sekitarnya. Pada jangka panjang akan membentuk karakter dan citra diri anggota BMT, seperti saling menolong, kekeluargaan, rela berkorban, jujur, saling menghormati, kerjasama, kesabaran, komunikatif, dan tidak egois. Karakter dan citra diri tersebut tak sekadar slogan, namun tercermin dalam cara hidup anggota koperasi di kehidupan sehari-hari.

Dalam pertemuan kelompok juga dirumuskan proses penerimaan/mengeluarkan anggota, penentuan berapa besar pinjaman yang bisa didapatkan oleh setiap anggota, kewajiban semua anggota (khususnya setoran angsuran), dan semua permasalahan yang terjadi di koperasi. Karena dilakukan secara musyawarah maka apapun hasil pertemuan harus ditaati seluruh anggota dalam kelompok tersebut.

Tanggung renteng membentuk nilai kedisiplinan setiap anggota BMT. Mereka harus disiplin waktu, disiplin dalam menjalankan aturan yang telah ditentukan pengelola maupun hasil kesepakatan kelompok. Pelanggaran terhadap kedisiplinan akan terkena sanksi, bukan saja si pelanggar sendiri tapi juga bisa seluruh anggota dalam kelompok tersebut.

Sebagai sistem, tanggung renteng merupakan alat kontrol dan kendali bagi pelbagai dinamika anggota dan keuangan (layanan kredit anggota) di tingkat kelompok. Oleh karena itu, syarat mutlak bisa diberlakukannya tanggung Renteng adalah adanya pengelompokkan.

\section{PEMBAHASAN}

Melalui produk-produk pembiayaan yang membuka akses yang luas bagi pengusaha UMK perempuan, khususnya Produk Pembiayaan Tanggung Renteng dapat dikatakan bahwa BMT merupakan lembaga keuangan yang sensitif gender' dan bisa semakin mendorong terwujudnya gender equalities. Selama ini pengusaha UMKM perempuan masih kurang mendapatkan akses dan dukungan sektor keuangan dari sektor lembaga keuangan khususnya perbankan. Hal ini antara lain karena masih berkembangnya anggapan bahwa perempuan adalah subordinat sehingga dianggap tidak penting potensi, partisipasi, dan 
aksesnya terhadap sumber-sumber keuangan.

Program-program atau produk-produk BMT yang memberikan akses yang terbuka bagi perempuan, dapat dikatakan memberi kesempatan pada kaum perempuan tersebut untuk menggali potensi dan memebrdayakan perempuan lewat kegiatan ekonomi dengan muatan kebutuhan strategis, karena perempuan dapat memenuhi kebutuhannya bahkan mempunyai penghasilan sendiri. Hal ini juga merupakan representasi kegiatan pembangunan yang menggunakan pendekatan gender dan pembagunan, mengharapkan kegiatan perempuan tidak terpaku hanya untuk pemenuhan kebutuhan keluarga, tetapi melibatkan perempuan untuk memenuhi kebutuhan masyarakat pada umumnya, khususnya melalui program/ Produk Pembiayaan Tanggung Renteng BMT. Perempuan yang dalam realitasnya telah terpinggirkan dalam kemiskinan karena multi beban yang mereka alami, dapat saling menguatkan dalam komunitas tanggung renteng tersebut. Mereka menjadi penerima manfaat sekaligus sebagai kontributor dan pelaksana, sehingga dapat megurangi struktur yang timpang dalam masyarakat.

Di samping itu, dengan menjadi anggota dari komunitas yang menjadi nasabah BMT, karena keberadaan BMT yang dekat dengan masyarakat, para perempuan tersebut tetap bisa menjalankan berbagai perannya. Terkait peranan perempuan dalam keluarga, perempuan merupakan benteng utama dalam keluarga, tetap menyadari fungsi dan peranannya sebagai istri dan ibu bagi anak-anak nya. Karena peningkatan kualitas sumber daya manusia dimulai dari peran perempuan dalam memberikan pendidikan kepada anaknya sebagai generasi penerus bangsa. Dalam hal ini komunitas kelompok Ibu-ibu tersebut juga biasanya mempunyai beberapa program yang menguatkan peran tersebut, misalnya pengajian.

Terkait peranan perempuan dalam pendidikan. Yang menjadikan BMT /Koperasi lebih unggul Dengan mengelola potensi perempuan melalai bidang pendidikan dan pelatihan dalam kelompok tersebut maka tenaga kerja perempuan akan semakin menempati posisi yang lebih terhormat untuk mampu mengangkat derajat bangsa.

Keberadaan BMT dan Produk-produknya yang acessable bagi perempuan, secara khusus dapat dikatakan mampu meningkatkan peranan perempuan dalam bidang ekonomi. Dengan membantu peningkatan ekonomi keluarga melalui berbagai jalur -dalam hal ini kewirausahaan-, maka diharapkan dapat meningkatkan pertumbuhan ekonomi yang akan memacu pertumbuhan industri (home industry), dan pada gilirannya akan mendorong peningkatan pemenuhan kebutuhan dan kualitas hidup.

Perempuan nasabah BMT tersebut bisa lebih memaksimalkan Al-quwwah al-aqliyyah yang mereka miliki, atau keunggulan potensi intelektual yang antara lain berfungsi melatih keahlian untuk menghasilkan sarana-sarana pendukung kehidupan (peradaban) dalam rangka memecahkan berbagai permasalahan dan mencapai maslahah. Dengan kata lain, program BMT telah mendukung pandangan Islam, karena perempuan juga dapat berkiprah dalam bidang ekonomi, melalui cara bekerjasama dengan elemen masyarakat lainnya dalam membangun peradaban yang luhur. Dalam dalam hal ini perempuan dan laki-laki, dapat bekerjasama memaksimalkan potensi dan peranannya dalam kehidupan, baik dalam peran produktif, peran reproduktif, ataupun peran sosial. Dalam kerangka pencapaian maslahah-yang dimensinya menyeluruh atau al-maslahab al kuliyyah dunia dan akhirat yang antara lain terlihat dari implikasinya terhadap terciptanya peradaban yang luhur sesuai dengan tuntutan Islam-, sebagai lembaga keuangan syariah yang memberikan akses yang luas bagi masyarakat golongan menegah ke bawah, BMT telah membangun konteks, sarana dan prasarana untuk mewujudkan al-maslahah al kuliyyah menjadi rasional. 
Dapat dikatakan bahwa produk BMT mampu menjadi program pemberdayaan masyarakat dan memfasilitasi suatu proses perubahan sosial yang berusaha untuk mengembangkan, mendirikan, serta memperkuat posisi tawar menawar orang-orang pinggiran yang tidak berdaya, atau masyarakat yang berada pada lapisan bawah terhadap kekuatan-kekuatan penekan di segala bidang dan sektor kehidupan. Hal ini antara lain dapat dijelaskan dalam beberapa hal berikut ini:

Pertama: BMT karena berbentuk badan hukum koperasi dapat menciptakan suasana atau iklim yang memungkinkan bagi berkembangnya potensi masyarakat dengan titik tolaknya adalah bahwa setiap manusia, termasuk perempuan, ataupun setiap kelompok masyarakat memiliki potensi yang dapat dikembangkan. Artinya tidak ada masyarakat yang sama sekali tanpa daya, karena bila demikian tentunya sudah akan punah. Pemberdayaan adalah upaya untuk mendorong, memotifasi, dan membangkitkan kesadaran akan potensi yang dimilikinya serta berupaya untuk mengembangkannya.

Kedua, BMT memperkuat potensi atau daya yang dimiliki oleh masyarakat (empowering), dilihat dari langkah-langkah yang lebih positif meliputi langkah-langkah nyata dan menyangkut penyediaan berbagai masukan (input) serta pembukaan akses ke dalam berbagai peluang (opportunities) yang akan membuat masyarakat (dalam hal ini Perempuan) menjadi semakin berdaya, dengan adanya program-program khusus bagi kelompok masyarakat yang kurang berdaya seperti Produk Pembiayaan Tanggung Renteng BMT, karena program-program umum yang berlaku untuk semua, tidak selalu dapat menyentuh lapisan masyarakat yang terpinggir atau yang terbawah.

Ketiga, karena memberdayakan mengandung arti melindungi,dalam proses pemberdayaan, BMT mencegah yang lemah menjadi bertambah lemah oleh karena kekurangberdayaan dalam menghadapi yang kuat.karena dapat mencegah terjadinya persaingan yang tidak seimbang, serta eksploitasi yang kuat atas yang lemah.peningkatan pendapatan yang dilakukan oleh penduduk miskin dengan memanfaatkan sumberdaya yang tersedia, meningkatnya kepedulian masyarakat terhadap upaya peningkatan kesejahteraan keluarga miskin, di lingkungannya, meningkatnya kemandirian kelompok (ditandai dengan makin kuatnya permodalan kelompok, makin rapinya sistem administrasi kelompok dan makin luasnya interaksi kelompok dengan kelompok lain dalam masyarakat), serta meningkatnya kapasitas masyarakat dan pemerataan pendapatan ditandai dengan peningkatan pendapatan keluarga miskin yang mampu memenuhi kebutuhan pokok dan kebutuhan sosial dasarnya.

Dalam kerangka membangun konteks untuk memaksimalkan peran perempuan baik dalam peran produktif, reproduktif, maupun sosialnya, kelompok binaan BMT dan BMT itu sendiri merupakan bentu penguatan masyarakat serta pranata-pranatanya. Dengan adanya pembaharuan institusi-institusi sosial dan pengintegrasiannya kedalam kegiatan pembangunan serta peranan masyarakat di dalamnya maka akan tercipta masyarakat yang berkeadilan, yang dibangun di atas landasan pemerataan bagi semua pihak termasuk perempuan.

Oleh karena itu, konsep BMT dengan berbagai produk dan layanannya telah berhasil mempertemukan pemikiran Islam dalam hal tersebut dengan wacana civil society, tampak menjanjikan sebagai solusi alternatif untuk mencapai perikehidupan yang lebih manusiawi dan bermartabat yang telah gagal dicapai baik oleh teori pembangunan yang mendasarkan pengoperasionalannya pada prinsip-prinsip ajaran Islam yang mempunyai concern terhadap pemberdayaan ekonomi rakyat miskin termasuk perempuan. Dengan menunjukkan perannya dalam mengayomi golongan masyarakat yang nampaknya 
termarjinalkan oleh kebijakan negara, institusi-institusi tersebut dapatlah dikatakan sebagai representasi dari wacana civil society.

BMT juga dapat dikatakan merupakan representasi dari program Kenangan Inklusif yang didefinisikan sebagai Hak setiap orang untuk memiliki akses dan layanan penuh dari lembaga keuangan secara tepat waktu, nyaman, informatif, dan terjangkau biayanya, dengan penghormatan penuh kepada harkat dan martabatnya, dalam hal ini harkat dan martabat perempuan yang tetap dapat menjalankan peran dan fungsinya secara baik. Mengembangkan BMT pada dasarnya mencapai tujuan pembangunan ekonomi yang lebih luas, yaitu penanggulangan kemiskinan dan peningkatan kesejahteraan masyarakat, serta bagian dari strategi untuk mencapai stabilitas sistem keuangan

Dari hasil kajian ini diharapkan dapat menjadi bahan rujukan yang valid bagi komponen lain-khususnya pemerintah dan sektor keuangan dan perbankan- untuk memberikan akses yang lebih luas bagi kaum perempuan terhadap sumber-sumber daya pembangunan serta berpartisipasi dan merasakan manfaat yang sama dalam proses pembangunan, sehingga dalam hal ini pola hubungan antara laki-laki dan perempuan menjadi lebih setara. Oleh karena itu kerangka pemikiran yang di pakai untuk menjelaskan signifikansi penelitian dengan issu pemberdayaan ekonomi perempuan ini ini dapat digambarkan sebagai berikut:

Gambar 1: Kerangka Pemikiran Pemberdayaan Ekonomi Perempuan Melalui BMT

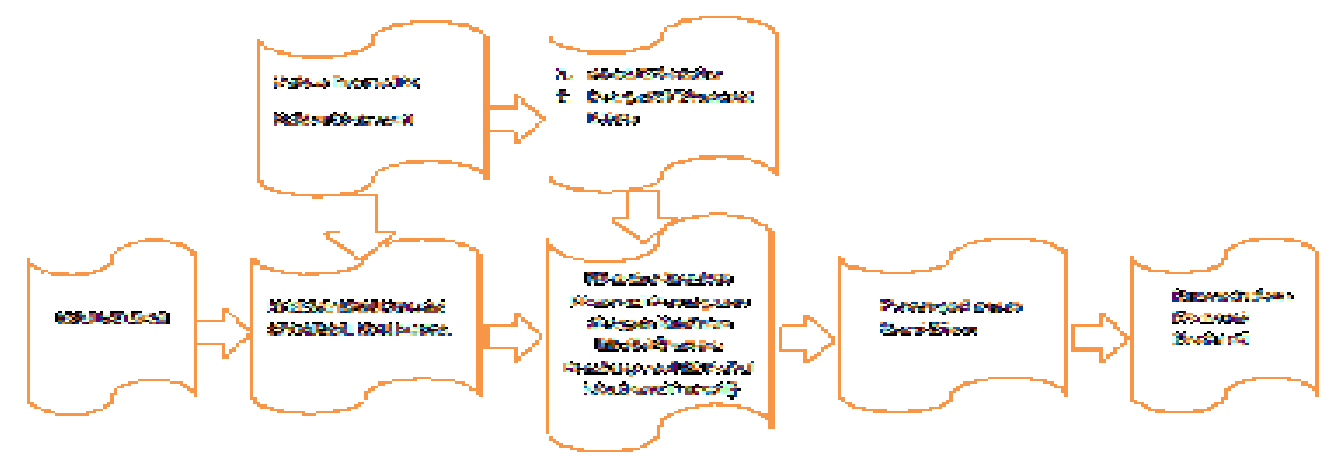

\section{KESIMPULAN}

BMT merupakan Lembaga Keuangan yang berbasis syariah yang accessible atau memberikan akses yang terbuka dan luas bagi para pengusaha perempuan, hal ini dapat dilihat dari relatif banyaknya perempuan yang menjadi nasabah pada beberapa BMT di Palembang yang dijadikan sampel dalam penelitian ini. Secara khusus untuk BMT Mitra Khazanah dan BMT Insan Mulia, adanya program Pembiayaan Tanggung Renteng, yang diperuntukkan bagi komunitas atau kelompok-kelompok tertentu termasuk kelompok perempuan (ibu-ibu), bisa membantu para pengusaha perempuan untuk meningkatkan usaha dan penghasilan mereka. Dalam hal ini dapat dikatakan BMT bukan hanya memberikan akses, tapi juga memberdayakan dengan membuat sistem pemberian modal yang berbasis kerjasama komunitas, karena kelompok secara bersama -sama merumuskan 
aturan pengembalian, bentuk cicilan, dan sebagainya, termasuk resiko dan keuntungan yang ditanggung bersama. Tanggung renteng membentuk nilai kedisiplinan setiap anggota BMT. Mereka harus disiplin waktu, disiplin dalam menjalankan aturan yang telah ditentukan pengelola maupun hasil kesepakatan kelompok. Pelanggaran terhadap kedisiplinan akan terkena sanksi, bukan saja si pelanggar sendiri tapi juga bisa seluruh anggota dalam kelompok tersebut.Sebagai sistem, tanggung renteng merupakan alat kontrol dan kendali bagi pelbagai dinamika anggota dan keuangan (layanan pembiayaan anggota) di tingkat kelompok. Oleh karena itu melalui sistem pembiayaan BMT ini, juga terkandung makna pemberdayaan, yaitu pemberdayaan kelompok pengusaha UMK Perempuan.

Melalui produk-produk pembiayaan yang membuka akses yang luas bagi pengusaha UMK perempuan, khususnya Produk Pembiayaan Tanggung Renteng dapat dikatakan bahwa BMT merupakan lembaga keuangan yang sensitif gender' dan bisa semakin mendorong terwujudnya gender equalities, karena secara demikian BMT telah menganggap penting potensi, partisipasi, dan akses pengusaha UMK Perempuan terhadap sumbersumber keuangan.

Keberadaan BMT dan Produk-produknya yang accessible bagi perempuan, secara khusus dapat dikatakan mampu meningkatkan peranan perempuan dalam bidang ekonomi. Dengan membantu peningkatan ekonomi keluarga melalui berbagai jalur -dalam hal ini kewirausahaan-, maka diharapkan dapat meningkatkan pertumbuhan ekonomi yang akan memacu pertumbuhan industri (bome industry), dan pada gilirannya akan mendorong peningkatan pemenuhan kebutuhan dan kualitas hidup. Di samping itu kaum Perempuan nasabah BMT tersebut bisa lebih memaksimalkan Al-quwwah al-aqliyyah yang mereka miliki, atau keunggulan potensi intelektual yang antara lain berfungsi melatih keahlian untuk menghasilkan sarana-sarana pendukung kehidupan (peradaban) dalam rangka memecahkan berbagai permasalahan dan mencapai maslahah khususnya dalam bidang ekonomi.

Dengan kata lain, program BMT telah mendukung pandangan Islam, karena perempuan juga dapat berkiprah dalam bidang ekonomi, melalui cara bekerjasama dengan elemen masyarakat lainnya dalam membangun peradaban yang luhur. Dalam dalam hal ini perempuan dan laki-laki, dapat bekerjasama memaksimalkan potensi dan peranannya dalam kehidupan, baik dalam peran produktif, peran reproduktif, ataupun peran sosial. Dalam kerangka pencapaian maslahah-yang dimensinya menyeluruh atau al-maslahah al kuliyyah dunia dan akhirat yang antara lain terlihat dari implikasinya terhadap terciptanya peradaban yang luhur sesuai dengan tuntutan Islam-, sebagai lembaga keuangan syariah yang memberikan akses yang luas bagi masyarakat golongan menegah ke bawah, BMT telah membangun konteks, sarana dan prasarana untuk mewujudkan al-maslahah al kuliyyah menjadi rasional.

\section{REFERENSI}

Antonio,M. Syafií (2017). Memberdayakan Kenangan Mikro Syariah Indonesia, Jakarta: BI. Kartono, Kartini (1989) Psikologi Wanita, Mengenal Gadis Remaja dan Wanita Dewasa. Bandung: Mandar Maju.

Faqih, Mansour(2012)Analisis Gender dan Transformasi Sosial.Penerbit: INSISTPress ISBN:979-3457-93-7Edisi/cetakan ke-14,November 2012

Kolasi: $13 \times 19 \mathrm{~cm}$; xxi +192 halaman

Katjasungkana, Nusyahbani. 2010. Potret Perempuan. Yogyakarta: Pustaka Pelajar.ISBN 10: 9799483522 ISBN 13: 9789799483522 
Rahayu, Angger Wiji, 2015,https://www.jurnalperempuan.org/wacanafeminis/perempuan-dan-belenggu-peran-kultural

UU No. 7 tahun 1984. Tentang Konvensi Mengenai Penghapusan Segala Bentuk Diskriminasi Terhadap Wanita (CEDAW).

Widuri, Endang. 2008. Pendidikan Hukum Perempuan sebagai Upaya Pemberdayaan Perempuan. Jurnal Yin Yang, Vol. 3, No. 2.

Sappleton, N. (2009), "Women non-traditional entrepreneurs and social capital", International Journal of Gender and Entrepreneurship, Vol. 1 No. 3, pp. 192218. https://doi.org/10.1108/17566260910990892

Nelson, T., Maxfield, S. and Kolb, D. (2009), "Women entrepreneurs and venture capital: managing the shadow negotiation", International Journal of Gender and Entrepreneurship, Vol. 1 No. 1, pp. 57-76. https://doi.org/10.1108/17566260910942345

Retno Ayu Purnama, Sari (2014), Pengarub Kinerja Kenangan Umk Terhadap Pemberdayaan Perempuan Yang Dimediasi Oleh Kontribusi Pendapatan Dalam Keluarga (Studi Kasus pada Nasabah Baitul Maal Wa Tamwil KUBE Sejabtera Kota Padang). Other thesis, Universitas Andalas.

Maftukhatusolikhah, Siti Mardiyah, Erdah Litriani, Sri Delasmi, (2018) Expanding Women's Access To The Banking Sector, International Journal of Islamic Business and Economics (IJIBEC), IAIN Pekalongan, hal. 131-144.

Robert K. Yin. (2012).Applications of Case Study Research, California, SAGE, ISBN: 1412989167,9781412989169 